\title{
Predictive Capacity of Boar Sperm Morphometry and Morphometric Sub-Populations on Reproductive Success after Artificial Insemination
}

\author{
Vinicio Barquero ${ }^{1}\left(\mathbb{D}\right.$, Eduardo R. S. Roldan $^{2}$, Carles Soler ${ }^{3}$, Jesús L. Yániz ${ }^{4}{ }^{\circledR}$, Marlen Camacho ${ }^{1}$ \\ and Anthony Valverde $1, *$ (i)
}

1 Animal Reproduction Laboratory, School of Agronomy, Costa Rica Institute of Technology, San Carlos Campus, Alajuela 223-21002, Costa Rica; vinicio1196@gmail.com (V.B.); mcamacho@tec.ac.cr (M.C.)

2 Department of Biodiversity and Evolutionary Biology, Museo Nacional de Ciencias Naturales (CSIC), 28006 Madrid, Spain; roldane@mncn.csic.es

3 Department of Cellular Biology, Functional Biology and Physical Anthropology, University of Valencia, Campus Burjassot, C/Dr Moliner 50, 46100 Burjassot, Spain; carles.soler@uv.es

4 BIOFITER Research Group, Higher Polytechnic School of Huesca, Institute of Environmental Sciences of Aragón (IUCA), University of Zaragoza, Ctra. Cuarte s/n, 22071 Huesca, Spain; jyaniz@unizar.es

* Correspondence: anvalverde@tec.ac.cr; Tel.: +506-2401-3223

check for updates

Citation: Barquero, V.; Roldan, E.R.S.; Soler, C.; Yániz, J.L.; Camacho, M.; Valverde, A. Predictive Capacity of Boar Sperm Morphometry and Morphometric Sub-Populations on Reproductive Success after Artificial Insemination. Animals 2021, 11, 920. https://doi.org/10.3390/ani11040920

Academic Editor: Juan Carlos Gardón Poggi

Received: 7 March 2021

Accepted: 22 March 2021

Published: 24 March 2021

Publisher's Note: MDPI stays neutral with regard to jurisdictional claims in published maps and institutional affiliations.

Copyright: (c) 2021 by the authors. Licensee MDPI, Basel, Switzerland. This article is an open access article distributed under the terms and conditions of the Creative Commons Attribution (CC BY) license (https:// creativecommons.org/licenses/by/ $4.0 /)$.
Simple Summary: The efficiency of swine production measured as litter size influences the profitability of the pig industry. Furthermore, sow fertility potential depends in part on the boar semen quality and reproductive efficiency. The objective of this study is to compare boar sperm head size and morphometric features of shape to evaluate their relationships with reproductive success after artificial insemination (AI). A morphometric analysis of boar ejaculate reveals morphometrically separate sub-populations. The differences between sub-populations are displayed for sperm head size. In addition, sperm clustering into sub-populations did not have a predictive capacity on litter size variables. Nevertheless, the morphometric variables of the sperm may have a predictive, albeit reduced, capacity regarding litter size variables. The results of this study therefore open up possibilities for future assessments of fertility.

Abstract: The aim of the study was to compare the morphometric features of sperm head size and shape from the Pietrain line and the Duroc $\times$ Pietrain boar crossbred terminal lines, and to evaluate their relationship with reproductive success after artificial insemination of sows produced from crossbreeding the York, Landrace and Pietrain breeds. Semen samples were collected from 11 sexually mature boars. Only ejaculates with greater than $70 \%$ motility rate and $<15 \%$ of abnormal sperm were used for artificial inseminations (AI) and included in the study. Samples were analyzed using an ISAS ${ }^{\circledR} \mathrm{v} 1$ computer-assisted sperm analysis system for eight morphometric parameters of head shape and size (CASA-Morph). Sub-populations of morphometric ejaculates were characterized using multivariate procedures, such as principal component (PC) analysis and clustering methods (kmeans model). Four different ejaculate sub-populations were identified from two PCs that involved the head shape and size of the spermatozoa. The discriminant ability of the different morphometric sperm variables to predict sow litter size was analyzed using a receiver operating characteristics (ROC) curve analysis. Sperm head length, ellipticity, elongation, and regularity showed significant predictive capacity on litter size $(0.59,0.59,0.60$, and 0.56 area under curve (AUC), respectively). The morphometric sperm sub-populations were not related to sow litter size.

Keywords: sperm; CASA-morph; fertility; sperm subpopulations; boar; sow; litter size 


\section{Introduction}

The efficiency of pig livestock production, measured as piglets born alive, total born per litter, and the number of piglets weaned by a sow per year, influence the profitability of the pig industry [1]. Sow fertility potential depends in part on the semen quality of the boar [2]. The ability to identify sub-fertile boars to improve reproductive efficiency has its basis in economic profitability [3]. The classical routine evaluation of boar fertility has traditionally been based on the assessment of semen variables, including seminal volume, sperm concentration, motility, and morphology [3]. Boars of different breeds, lines, or crossbreeds can produce ejaculates of different volumes, sperm concentrations, motilities, and kinematic patterns $[4,5]$. Sperm morphometry differs according to the breed of the male [6]. It has been reported that considerable variability exists in sperm morphometry among males from the same population [7-10]. Furthermore, the sperm morphometry variability of different ejaculates from the same animal has been documented [11]. Interest in the size and shape morphometry of sperm heads has led to intense research in recent years $[12,13]$. The morphometric variables of the size and shape of the sperm head exhibit a relevant variability among species, among males of different species [14,15], and between breeds or selected lines within a species $[6,10]$. Some studies have described a correlation between the fertility of males used for artificial insemination (AI) and sperm morphometry [12], and head size has been associated with factors predisposing fertility [16]. Other authors refer to an association between the head size and shape of the spermatozoa and semen or ejaculate variables [17-19]. The total spermatozoa in the ejaculate have been associated with the morphometric variables of spermatozoa: ejaculates with a low sperm concentration have smaller, shorter, and narrower head sizes and a smaller head area than those of ejaculates with a high sperm count [8]. Current computer-assisted sperm morphometric analysis CASA-Morph systems can be used to analyze individual sperm morphometrics more accurately, and this information can be submitted to a multivariate procedure such as cluster analysis for an overview of distinct sperm patterns grouped into sub-populations (SPs) or clusters [20]. Some authors have indicated that the distribution of spermatozoa in each sperm sub-population can vary among males, and some of these sub-populations have been correlated with sperm quality [21]. Several studies have examined the association between sperm head size and fertility in pigs $[6,16,22]$ and species such as cattle [23], buffalo [24], sheep [25], goats [26], horses [27], dogs [28]. or humans [29]. A limited number of studies have focused on the size and head shape of sperm and the characterization of sperm sub-populations on litter size in livestock species such as pigs $[30,31]$. Even today, the biological relevance and direct biological meaning of sperm sub-populations remain controversial. The aim of the present study was to compare the morphometric features of the head size and shape of spermatozoa from the Pietrain and Duroc $\times$ Pietrain boar crossbred terminal lines, and to evaluate their relationships with the litter size of sows produced from crossbreeding of the York, Landrace, and Pietrain breeds.

\section{Materials and Methods}

\subsection{Animals}

The experiment was conducted at a commercial swine farm (Agropecuaria Los Sagitarios S.A., Alajuela, Costa Rica) during 2019-2020 in the northwest of Costa Rica (Río Cuarto, $10^{\circ} 20^{\prime} 32^{\prime \prime} \mathrm{N}, 84^{\circ} 12^{\prime} 55^{\prime \prime} \mathrm{W}$, Alajuela, Costa Rica, Central America) following the laws and regulations controlling experiments on live animals in Costa Rica. This study was performed following ethical principles, and with the approval of the Committee of Centro de Investigación y Desarrollo de la Agricultura Sostenible para el Trópico Húmedo at the Costa Rica Institute of Technology (CIDASTH-ITCR) according to Section 08/2020, article 1.0, DAGSC-100-2020. Eleven sexually mature and healthy boars from two commercial terminal male lines (ML: Duroc $\times$ Pietrain $(n=8)$ and Pietrain boars $(n=3)$ ), $20.9 \pm 3.0$ (Pietrain) and $24.1 \pm 9.8$ (Duroc $\times$ Pietrain) months of age at the beginning of the experiment and of known fertility were used as semen donors in this study. For the study, the breeding boars were housed individually in well-ventilated pens with an 
average temperature of $25.6 \pm 2.94{ }^{\circ} \mathrm{C}$ during the time of the experiment. The females came from four crossbred genetic lines (FL: York (Y), Landrace (L) and Pietrain (P), with the crossing schemes YLP-50 $\left(\frac{1}{4} \mathrm{Y} \times \frac{1}{4} \mathrm{~L} \times \frac{1}{2} \mathrm{P}\right)$, YLP-75 $\left(1 / 8 \mathrm{Y} \times 1 / 8 \mathrm{~L} \times{ }^{3} /{ }_{4} \mathrm{P}\right), \mathrm{YLP}-87.5$ $\left(1 /{ }_{16} \mathrm{Y} \times{ }^{1} /{ }_{16} \mathrm{~L} \times{ }^{7} / 8 \mathrm{P}\right)$, and $\left.\mathrm{Y}-\mathrm{L}-50\left(\frac{1}{2} \mathrm{Y} \times \frac{1}{2} \mathrm{~L}\right)\right)$. All of the females were bred on the farm and they came from maternal crossing schemes. Animals were fed with a standard breeder mixture (made on the farm) containing maize, soybean meal, mineral mixture, and common salt, as ingredients to fulfill the nutrient requirements according to the Nutrient Requirements of Swine [32]. Pregnant sows were provided with $2.5 \mathrm{~kg}$ of concentrated feedstuff in the first $2 / 3$ of the gestation period and $3 \mathrm{~kg}$ in the final third. Males consumed $2.5 \mathrm{~kg}$ of concentrated feedstuff per day and were provided with water ad libitum. The gilts inseminated were 7 months of age, with a minimum weight of $145 \mathrm{~kg}$.

\subsection{Fertility Trial}

A total of 816 triple-artificial inseminations, performed with homospermic ejaculates, were evaluated on 272 sows. These AIs were conducted aleatory with 40 ejaculates from eleven males. That means that each genetic line of females was randomly inseminated with each genetic line of males. Each ejaculate was used in the first 3 days post-collection, and only those used to inseminate at least three females were evaluated. The mean of sows inseminated per boar was $24.7 \pm 10.1$ females. These AI resulted in $3.99 \pm 3.16$ farrowings from each female. Parameters measured at the time of farrowing were: litter size as total piglets born (TPB) per litter, piglets born alive (PBA), piglets born dead (PBD), number of mummies (MP), and litter weight (LW; kg).

\subsection{Collection and Examination of Semen}

Semen samples were collected in the morning, once per week, using the "gloved-hand" technique [33], and immediately placed into a water bath at $37^{\circ} \mathrm{C}$ at the farm laboratory. In all cases, the sperm-rich fractions were collected and diluted with a commercial extender (Zoosperm ND5; Import-Vet, Barcelona, Spain). Insemination doses contained $3.7 \pm 1.3 \times 10^{9}$ spermatozoa. From each boar, $3.64 \pm 0.81$ ejaculates were obtained. Samples from each ejaculate were evaluated for motility, and only ejaculates with at least $70 \%$ motile spermatozoa and 85\% morphologically normal spermatozoa were used. The concentration was measured with Spermacue (Minitube, $\mathrm{GmbH}$, Tiefenbach, Germany), following established protocols. Samples were stored at $17^{\circ} \mathrm{C}$ and then transported to the laboratory in the same refrigerated conditions used for commercial distribution $\left(17^{\circ} \mathrm{C}\right)$. A volume of one milliliter $(1 \mathrm{~mL})$ of mixed sample was placed in an Eppendorf ${ }^{\circledR}$ tube (Sigma-Aldrich, St. Louis, MO, USA) and maintained at $37^{\circ} \mathrm{C}$ for $30 \mathrm{~min}$ before use.

\subsection{Sample Preparation for Morphometric Analysis}

Duplicate samples for morphometric analysis were prepared from the ejaculates of each commercial line. After being mixed, $10 \mu \mathrm{L}$ of each sample was spread on a glass slide and subsequently air-dried. The slides were stained using the Diff-Quik ${ }^{\circledR}$ kit (Medion Diagnostics, Düdingen, Switzerland), following the instructions of the manufacturer. All the slides were identified and then analyzed in a double-blind scheme.

\subsection{Assessment of Sperm Variables}

Microscope slides were analyzed for sperm head morphometry using the ISAS ${ }^{\circledR}$ v1 (Integrated Semen Analysis System, Proiser R+D, Valencia, Spain). The equipment comprised of a UB203 microscope (UOP/Proiser R+D) equipped with a bright-field $100 \times$ objective and a $3.3 \times$ photo-ocular. A digital video camera (Proiser $782 \mathrm{~m}$, Proiser R+D) was mounted on the microscope to capture the images and transmit them to the computer. The array size of the video frame grabber was $746 \times 578 \times 8$ bit, providing a resolution of the analyzed images of $0.084 \mu \mathrm{m} /$ pixel in both axes, and 256 gray levels. The resolution of the images was $0.08 \mu \mathrm{m}$ per pixel in both the horizontal and vertical axes. The sperm heads were captured randomly in different fields, and only those that overlapped with 
background particles or other cells so as to interfere with the subsequent image processing were rejected. An Initial erroneous definition of the sperm head boundary was corrected by varying the analysis factor of the system. When it was not possible to obtain a correct boundary, the sperm head was deleted from the analysis.

For the analysis of motility, ISAS ${ }^{\circledR}$ D4C20 disposable counting chambers (Proiser R+D., Paterna Spain) were used after being pre-warmed to $37^{\circ} \mathrm{C}$. After homogenization of the samples, a volume of $3 \mu \mathrm{L}$ was distributed along the counting chamber race by capillarity to fill it completely. Analyses were conducted using the CASA-Mot system of an ISAS ${ }^{\circledR}$ v1 (Proiser R+D S.L., Paterna, Spain). The frame rate used was $50 \mathrm{~Hz}$, with the final resolution of the images being $746 \times 578$ pixels. The camera was attached to a UB203 microscope (UOP/Proiser R+D) with a $1 \times$ eyepiece and a $10 \times$ negative phase contrast objective (AN 0.25) and an integrated heated stage was maintained at a constant temperature of $37 \pm 0.5^{\circ} \mathrm{C}$. The CASA settings used were: a particle area between 10 and $80 \mu \mathrm{m}^{2}$, and connectivity of $11 \mu \mathrm{m}$. The percentage of total motile cells and progressive motility (\%) corresponded to the spermatozoa swimming forward quickly in a straight line. The parameters defining progressive motility were straightness (STR) $\geq 45 \%$, and average path velocity $(\mathrm{VAP}) \geq 25 \mu \mathrm{m} / \mathrm{s}$, defined as the average velocity over a smoothed cell path.

A single technician carried out the assessments of sperm morphology. Sperm were classified as having normal or abnormal morphologic features following WHO strict criteria [34]. A total of 200 sperm were analyzed per slide, and 100 sperm from each of two different locations on the slide were assessed. If the difference between the percentage of normal sperm in the two areas was 5 percentage points or lower, the mean value was calculated.

\subsection{Morphometric Analysis}

Images from about 200 spermatozoa from each sample were captured and analyzed to obtain eight morphometric variable values. Following the criteria of Boersma [35], the sperm heads were measured on each slide for four primary parameters of head size, length $(\mathrm{L}, \mu \mathrm{m})$, width $(\mathrm{W}, \mu \mathrm{m})$, area $\left(\mathrm{A}, \mu \mathrm{m}^{2}\right)$, and perimeter $(\mathrm{P}, \mu \mathrm{m})$; and four derived dimensionless parameters of head shape, ellipticity $(\mathrm{L} / \mathrm{W})$, rugosity $\left(4 \pi \mathrm{A} / \mathrm{P}^{2}\right)$, elongation $((\mathrm{L}-\mathrm{W}) /(\mathrm{L}+\mathrm{W}))$, and regularity $(\pi \mathrm{LW} / 4 \mathrm{~A})$. Data from each individual sperm cell were saved in a database compatible with Excel ${ }^{\circledR}$ (Microsoft Corporation, Redmond, Washington, DC, USA) by the software for further analysis.

\subsection{Statistical Analysis}

The data obtained for the analysis of all sperm parameters were first assessed for normality and homoscedasticity using the Shapiro-Wilks and Levene tests. A normal probability plot was used to assess normal distribution. Multivariate analyses were performed to identify sperm sub-populations from the set of ejaculate sperm morphometric data. All of the values for the morphometric variables were standardized to avoid any scale effect or variables with larger scales from dominating how clusters were defined. Thus, all variables were considered by the algorithm to be of equal importance. The standardization used was Z-score, and it transformed data by subtracting the mean value for each field from the values of the file, and then dividing by the standard deviation of the field, resulting in data with a mean of zero and a standard deviation of one. Differences between means were analyzed using a Bonferroni test. Results are presented as mean \pm standard deviation (s.d.). Statistical significance was considered at $p<0.05$. All data were analyzed using the IBM SPSS software package version 23.0 for Windows (SPSS Inc., Chicago, IL, USA).

\subsubsection{Multivariate Procedures}

A subset of the data was created using the means per ejaculate of all eight morphometric variables. The first process carried out was a principal component analysis (PCA) of the morphometric data to derive a small number of linear combinations that still retained as much information as possible from the original variables. The number of principal 
components (PC) used in the next part of the analysis was determined using the Kaiser criterion, namely selecting only those with an eigenvalue (variance extracted of each PC) $>1$. Furthermore, Bartlett's sphericity test and the Kaiser-Meyer-Olkin (KMO) measure were performed [36]. As a rotation method, the varimax method with Kaiser normalization was used [37].

An analysis was conducted to classify the ejaculates into a reduced number of subpopulations (clusters), based on the scores obtained from the factor analysis. This was accomplished in two phases combining hierarchical and non-hierarchical clustering procedures. The process to perform a non-hierarchical analysis was conducted with a k-means model that used Euclidean distances from the quantitative variables after the standardization of these data, so the cluster centers were the means of the observations assigned to each cluster [38]. The multivariate k-mean cluster analysis was made to classify the ejaculates into a reduced number of sub-populations (clusters) according to their morphometric variables. In the final process, to determine the optimal number of clusters, the final centroids were clustered hierarchically using the Ward method [39]. Thus, the clustering procedure enabled the identification of sperm sub-populations because each cluster contributed to a final cluster formed by the ejaculate linked to the centroids. Then, ANOVA procedures were applied to evaluate statistical differences in the distributions of observations (individual spermatozoa) within the sub-populations, and then a generalized linear model (GLM) procedure was used to determine the effects of the genetic lines of the boar and sow breeds on the mean morphometric variable values defining the different sperm sub-populations (e.g., the cluster centers).

\subsubsection{ROC Analysis}

The diagnostic test with a dichotomous outcome (positive/negative fertility test results) of the different morphometric semen variables to predict litter size variables was analyzed using receiver operating characteristic (ROC) curve analysis. This diagnostic test evaluation used sensitivity and specificity as measures of test accuracy when compared with a standard status (farrowing). The sensitivity (true positive rate) and specificity (true negative rate) of each morphometric parameter varied across the different thresholds, and the sensitivity was inversely related to the specificity. The plot of sensitivity versus the 1-specifity is called the receiver operating characteristic (ROC) curve and the area under the curve (AUC). AUC varies from 0.5 (test with no discriminatory ability) to 1 (perfect discriminatory ability). A ROC was also used to calculate the elective breaking point (cut-off value) of each morphometric sperm variable. The analysis may also be used to determine the optimal cut-off value (optimal decision threshold).

\section{Results}

\subsection{Overall Semen Variables}

The sperm concentration, the volume of semen, and the total spermatozoa in the ejaculate were $374.23 \pm 129.24 \times 10^{6} / \mathrm{mL}, 231.98 \pm 63.08 \mathrm{~mL}$, and $82.04 \pm 23.73 \times 10^{9}$, respectively. The sperm concentration (million/mL) was $378.63 \pm 134.98$ in the Duroc $\times$ Pietrain crossbreed and $361.00 \pm 112.35$ in the Pietrain. The total motility (\%) of the boar samples was $77.36 \pm 11.17$, with an overall range of $35.05-93.69 \%$. The progressive motility of the sperm (\%) was $63.76 \pm 11.96$. The average total motility $(\%)$ for the Duroc $\times$ Pietrain and the Pietrain boars was $81.28 \pm 7.76$, and $65.61 \pm 11.73$, respectively. The progressive motility (\%) was $67.00 \pm 10.05$ (Duroc $\times$ Pietrain), and $54.04 \pm 12.19$ (Pietrain).

\subsection{Morphometric Variables}

There was an animal effect on the sperm head size variables $(p<0.05$; Figure 1 ; supplementary Table S1). The sperm head size from the Duroc $\times$ Pietrain boars was, in fact, larger than the sperm head size of the Pietrain boars. The sperm from the Duroc $\times$ Pietrain boar ejaculates had a larger head perimeter $(0.5 \mu \mathrm{m})$ and head area $\left(1.26 \mu \mathrm{m}^{2}\right)$ than the sperm from the Pietrain boar ejaculates $(p<0.05)$. The Duroc $\times$ Pietrain ejaculates 
contained longer $(0.15 \mu \mathrm{m})$ and wider $(0.08 \mu \mathrm{m})$ sperm than did the Pietrain ejaculates $(p<0.05)$. There were no differences in the shape of the sperm heads between the boar breeds and the AI semen doses used for females insemination (Table 1).
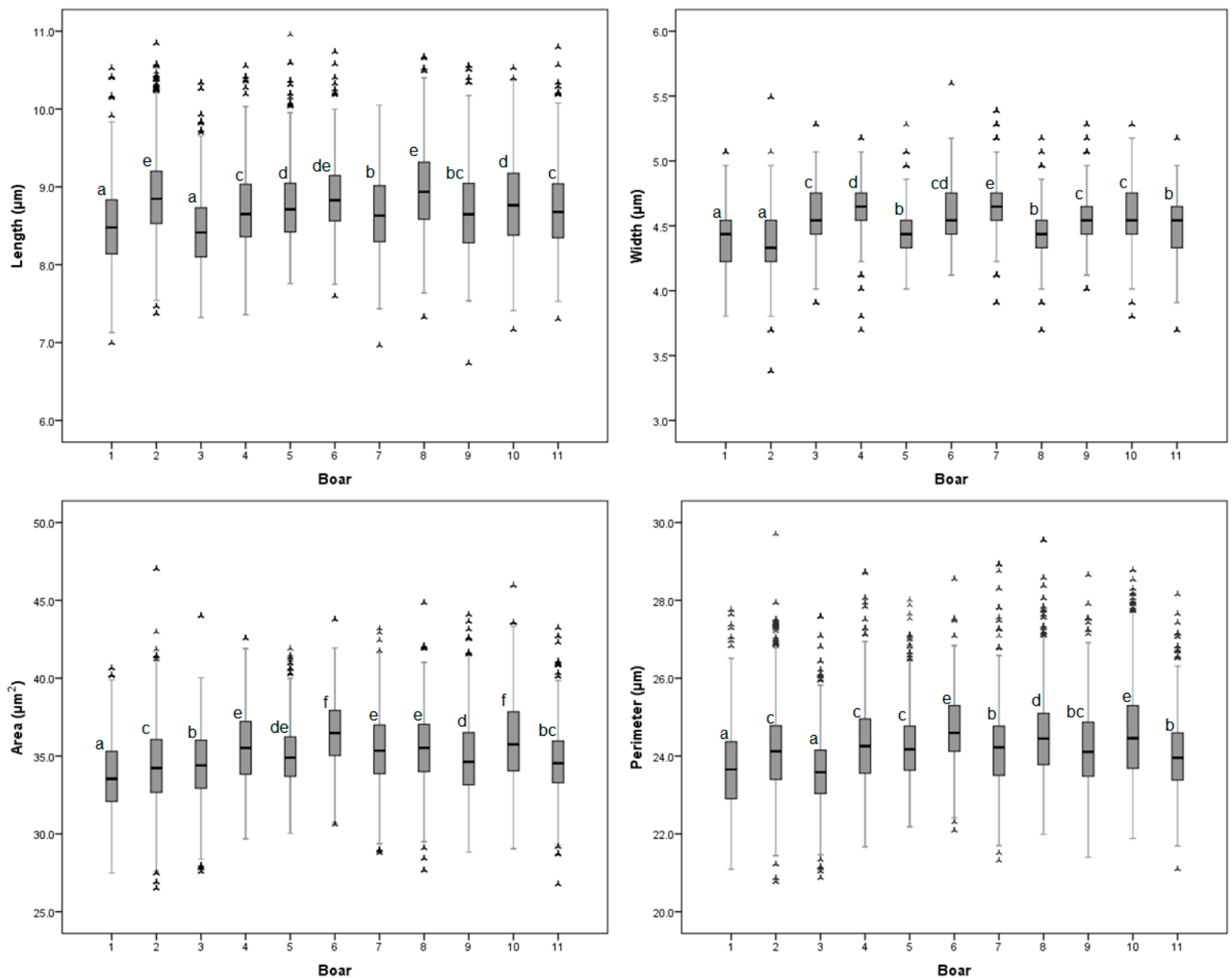

Figure 1. Box and whisker plot of distribution of boar sperm head size morphometric variables. Each box contains the central $50 \%$ of the observations and the whisker contains the central $95 \%$. ${ }^{\text {a-f }}$ Boxes labelled with different letters indicate differences between boars. $p<0.05$.

Table 1. Morphometric variables (mean \pm s.d.) of boar sperm size and head shape of in different crossbred males and AI doses use in sows.

\begin{tabular}{ccccccc}
\hline & \multicolumn{3}{c}{ Boar } & \multicolumn{3}{c}{ Sows } \\
\hline Variable & Pietrain & $\mathbf{D} \times \mathbf{P}$ & YLP-50 & YLP-75 & YLP-87.5 & Y-L-50 \\
\hline Length & $8.62 \pm 0.60^{\alpha}$ & $8.77 \pm 0.53^{\beta}$ & $8.70 \pm 0.52^{\mathrm{a}}$ & $8.78 \pm 0.55^{\mathrm{c}}$ & $8.74 \pm 0.53^{\mathrm{b}}$ & $8.75 \pm 0.56^{\mathrm{b}}$ \\
Width & $4.46 \pm 0.23^{\alpha}$ & $4.54 \pm 0.22^{\beta}$ & $4.50 \pm 0.23^{\mathrm{a}}$ & $4.53 \pm 0.22^{\mathrm{c}}$ & $4.51 \pm 0.23^{\mathrm{b}}$ & $4.51 \pm 0.22^{\mathrm{b}}$ \\
Area & $34.20 \pm 2.47^{\alpha}$ & $35.46 \pm 2.39^{\beta}$ & $34.94 \pm 2.33^{\mathrm{a}}$ & $35.38^{\alpha} \pm 2.53^{\mathrm{c}}$ & $35.08 \pm 2.46^{\mathrm{b}}$ & $35.07 \pm 2.28^{\mathrm{b}}$ \\
Perimeter & $23.84 \pm 1.13^{\alpha}$ & $24.34 \pm 1.06^{\beta}$ & $24.15 \pm 1.03^{\mathrm{a}}$ & $24.31 \pm 1.11^{\mathrm{c}}$ & $24.23 \pm 1.05^{\mathrm{b}}$ & $24.19 \pm 1.06^{\mathrm{ab}}$ \\
Ellipticity & $1.94 \pm 0.17$ & $1.94 \pm 0.14$ & $1.94 \pm 0.15$ & $1.94 \pm 0.14$ & $1.95 \pm 0.15$ & $1.94 \pm 0.15$ \\
Rugosity & $0.76 \pm 0.04$ & $0.75 \pm 0.04$ & $0.75 \pm 0.04$ & $0.75 \pm 0.03$ & $0.75 \pm 0.04$ & $0.75 \pm 0.04$ \\
Elongation & $0.32 \pm 0.04$ & $0.32 \pm 0.03$ & $0.32 \pm 0.02$ & $0.32 \pm 0.03$ & $0.32 \pm 0.03$ & $0.32 \pm 0.04$ \\
Regularity & $0.88 \pm 0.03$ & $0.88 \pm 0.04$ & $0.88 \pm 0.03$ & $0.88 \pm 0.04$ & $0.88 \pm 0.04$ & $0.88 \pm 0.03$ \\
\hline
\end{tabular}

AI: artificial insemination, s.d.: standard deviation, length $(\mathrm{L}, \mu \mathrm{m})$, width $(\mathrm{W}, \mu \mathrm{m})$, area $\left(\mathrm{A}, \mu \mathrm{m}^{2}\right)$, perimeter $(\mathrm{P}, \mu \mathrm{m})$, ellipticity $(\mathrm{L} / \mathrm{W})$, rugosity $\left(4 \pi \mathrm{A} / \mathrm{P}^{2}\right)$, elongation $\left.(\mathrm{L}-\mathrm{W}) /(\mathrm{L}+\mathrm{W})\right)$, regularity $(\pi \mathrm{LW} / 4 \mathrm{~A})$. $\mathrm{Y}$ : York, L: Landrace, P: Pietrain, D: Duroc. YLP-50 $=\left(\frac{1}{4} \mathrm{Y} \times\right.$ $\left.\frac{1}{4} \mathrm{~L} \times \frac{1}{2} \mathrm{P}\right), \mathrm{YLP}-75=\left(1 / 8 \mathrm{Y} \times 1 / 8 \mathrm{~L} \times{ }^{3} /{ }_{4} \mathrm{P}\right), \mathrm{YLP}-87.5=\left({ }^{1} /{ }_{16} \mathrm{Y} \times 1 / 16 \mathrm{~L} \times{ }^{7} /{ }_{8} \mathrm{P}\right), \mathrm{Y}-\mathrm{L}-50:{ }^{1} / 2 \mathrm{Y} \times{ }^{1} / 2 \mathrm{~L} .{ }^{\alpha, \beta}$ Different letters indicate differences between crossbred males. ${ }^{\mathrm{a}-\mathrm{c}}$ Different letters indicate differences between crossbred females. $p<0.05$. 
The indices used to evaluate the differences in the dimension of sperm from ejaculates indicate differences between the males in head size. The percentage of variation of the morphometric traits between the ejaculates with the lowest and highest sperm head sizes were $5.02 \%$ for length, $6.17 \%$ for width, $5.31 \%$ for the area, $4.09 \%$ for perimeter, $9.76 \%$ for ellipticity, and $3.90 \%$ for rugosity. The sperm doses used on the YLP-75 sows evaluated had a larger sperm head size $(p<0.05)$ than the sperm doses on the YLP-50 sows $\left(0.44 \mu \mathrm{m}^{2}\right.$ larger on average). There were no differences $(p>0.05)$ for the sperm head size variables between the YLP-87.5 and Y-L-50 female lines (Table 1).

\subsection{Fertility Traits}

The mean fertility rate was $69.6 \pm 21.67 \%$. There were no differences between the male lines for this variable. The Sows inseminated with the Duroc $\times$ Pietrain semen had a larger $(p<0.05)$ total number born per litter $(10.53 \pm 3.94)$ than those inseminated with the Pietrain semen $(9.72 \pm 4.24)$. In the Duroc $\times$ Pietrain crossbreed, the number of piglets born alive $(\mathrm{PBA}=9.46 \pm 3.70)$ and piglets born dead $(\mathrm{PBD}=0.80 \pm 1.11)$ were higher than those of the Pietrain boars $(\mathrm{PBA}=8.89 \pm 3.77, \mathrm{PBD}=0.65 \pm 0.95 ; p<0.05)$. Litter weight at birth and number of mummies were lower for the Pietrain boars $(p<0.05$; Table 2$)$. There was an animal effect on litter size variables and litter weight at birth $(p<0.05$; Figure 2; supplementary Table S2).

Table 2. Fertility variables (mean \pm s.d.) of litter size and piglet mortality of according to source of boar semen and in different lines of sows.

\begin{tabular}{|c|c|c|c|c|c|c|}
\hline \multirow[b]{2}{*}{ Variable } & \multicolumn{2}{|c|}{ Boar } & \multicolumn{4}{|c|}{ Sows } \\
\hline & Pietrain & $\mathbf{D} \times \mathbf{P}$ & YLP-50 & YLP-75 & YLP-87.5 & Y-L-50 \\
\hline Total born per litter & $9.72 \pm 4.24^{\alpha}$ & $10.53 \pm 3.94^{\beta}$ & $10.12 \pm 3.54^{\mathrm{a}}$ & $10.37 \pm 4.03^{b}$ & $10.01 \pm 3.89^{a}$ & $10.76 \pm 4.55^{c}$ \\
\hline Piglets born alive & $8.89 \pm 3.77^{\alpha}$ & $9.46 \pm 3.70^{\beta}$ & $8.71 \pm 3.39^{a}$ & $9.26 \pm 3.53^{b}$ & $9.25 \pm 3.64^{b}$ & $9.64 \pm 4.30^{c}$ \\
\hline Piglets born dead & $0.65 \pm 0.95^{\alpha}$ & $0.80 \pm 1.11^{\beta}$ & $1.13 \pm 1.08^{\mathrm{d}}$ & $0.88 \pm 1.33^{c}$ & $0.55 \pm 1.00^{\mathrm{a}}$ & $0.77 \pm 0.69^{b}$ \\
\hline Number of mummies & $0.19 \pm 0.35^{\alpha}$ & $0.26 \pm 0.64^{\beta}$ & $0.28 \pm 0.6^{b}$ & $0.23 \pm 0.56^{\mathrm{a}}$ & $0.22 \pm 0.51^{\mathrm{a}}$ & $0.35 \pm 0.75^{c}$ \\
\hline Litter weight at birth & $14.23 \pm 5.74^{\alpha}$ & $15.58 \pm 5.59^{\beta}$ & $13.95 \pm 4.75^{\mathrm{a}}$ & $15.44 \pm 5.43^{c}$ & $15.16 \pm 5.72^{b}$ & $15.05 \pm 6.27^{b}$ \\
\hline
\end{tabular}

s.d.: standard deviation. Y: York, L: Landrace, P: Pietrain, D: Duroc. YLP-50 $=\left(\frac{1}{4} \mathrm{Y} \times \frac{1}{4} \mathrm{~L} \times \frac{1}{2} \mathrm{P}\right), \mathrm{YLP}-75=\left(1 / 8 \mathrm{Y} \times 1 / 8 \mathrm{~L} \times{ }^{3} / 4 \mathrm{P}\right)$, YLP-87.5 $=\left({ }^{1} /{ }_{16} \mathrm{Y} \times 1 / 16 \mathrm{~L} \times{ }^{7} / 8 \mathrm{P}\right), \mathrm{Y}$-L-50: ${ }^{1} / 2 \mathrm{Y} \times 1 / 2 \mathrm{~L}$. Litter weight at birth $(\mathrm{kg}) .{ }^{\alpha, \beta}$ Different letters indicate differences between crossbred males. ${ }^{\mathrm{a}-\mathrm{d}}$ Different letters indicate differences between crossbred females. $p<0.05$.

Fertility traits such as total born per litter $(10.76 \pm 4.55)$, piglets born alive (9.64 \pm 4.30$)$, and the number of mummies $(0.35 \pm 0.75 ; p<0.05)$ were higher in the Y-L-50 crossbred females than in the other lines. The YLP-87.5 crossbred sows presented a lower $(p<0.05)$ number of piglets born dead $(0.55 \pm 1.00)$. The YLP-50 sows had fewer piglets born alive $(p<0.05)$. The litter weight at birth was higher in the YLP-75 sows (Table 2).

\subsection{Sub-Population Structure}

Results from the principal component analysis revealed two PC factors. PC1 was referred to as "head shape," or long, stretched, tubiform cells, which were represented by the elongation, ellipticity, head length, and rugosity (in reverse order). The larger eigenvector corresponded to elongation (0.47). PC2 was represented by the sperm head area, perimeter, and width, and was named "head size." It is mainly related to the head area (Eigenfactor $=0.55)$ (Table 3$)$. These results indicate that the shape and head size of sperm have a relatively greater effect $(86.2 \%)$ on the total variance explained, and the elongation and ellipticity showed a maximum correlation (Figure 3). 

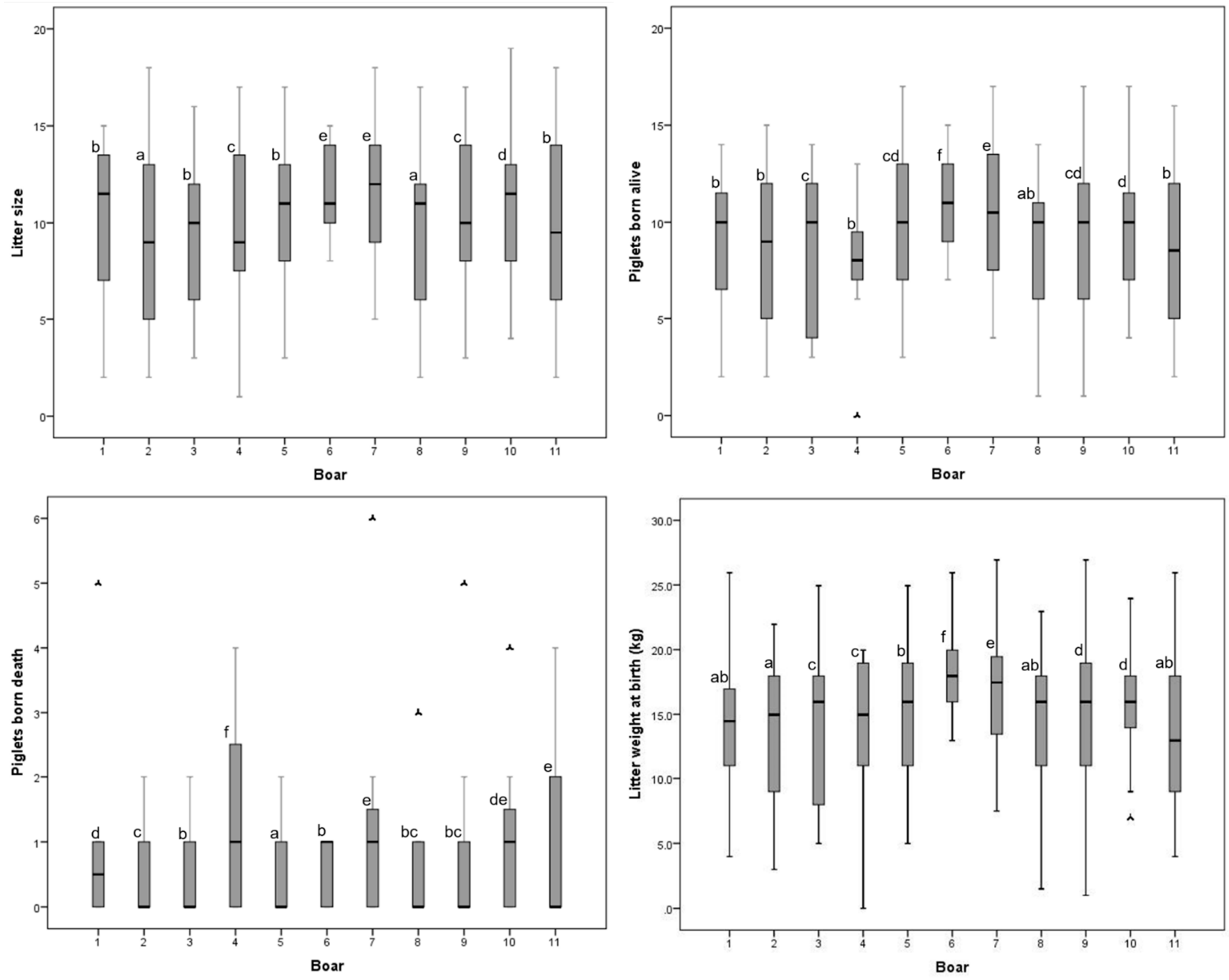

Figure 2. Box plot of distribution of litter size and other litter variables for the different boars. Each box contains the central $50 \%$ of the observations, and the whisker contains the central $95 \%$. ${ }^{\text {a-f }}$ Boxes labelled with different letters indicate differences between boars. $p<0.05$.

Table 3. Eigenvectors of principal components (PCs) * for the morphometric variables of boar sperm size and head shape.

\begin{tabular}{ccc}
\hline Variable & $\mathbf{P C}_{\mathbf{1}}$ & $\mathbf{P C}_{\mathbf{2}}$ \\
\hline Length & 0.44 & \\
Width & & 0.54 \\
Area & & 0.55 \\
Perimeter & 0.46 & 0.45 \\
Ellipticity & -0.46 & \\
Rugosity & 0.47 & \\
Elongation & & \\
Regularity & 50.6 & 35.6 \\
\hline Var Exp
\end{tabular}

Var Exp: variance explained in each PC. Total variance explained $=86.2 \% .{ }^{*}$ Expresses the more important variables in each PC. Only eigenvectors $>0.4$ are presented. 


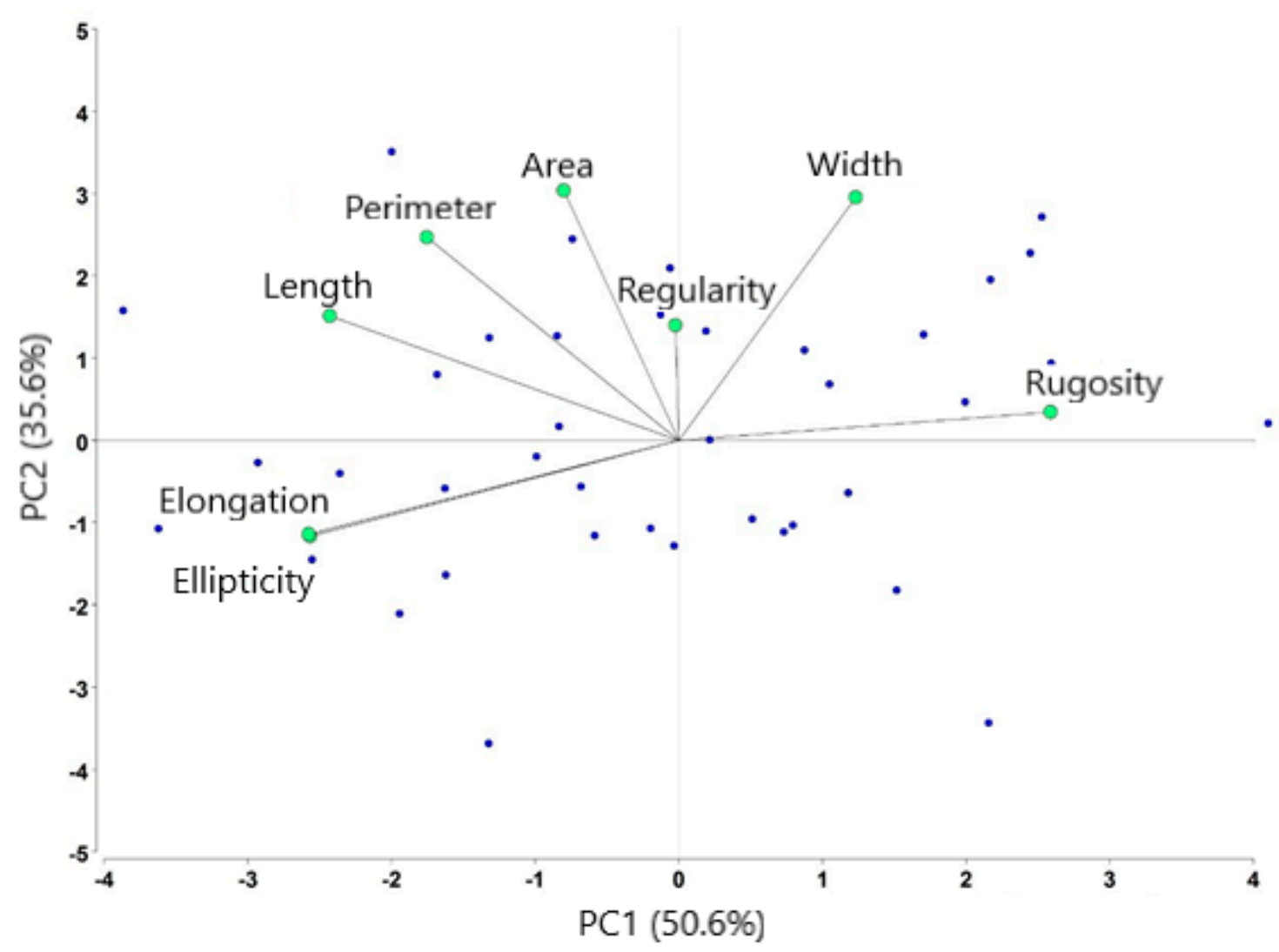

Figure 3. Distribution of morphometric variables after principal component analysis. Each blue point represents an ejaculate. Four sperm sub-population were identified from forty ejaculates.

Four sperm subpopulations (SPs) with different morphometric patterns were obtained from the morphometry traits. Summary data for the morphometrics and SP fertility are presented in Table 4. They can be summarized as follows: sub-population 1 (SP1) included ejaculates with lower values for ellipticity $(1.83 \pm 0.03)$ and the widest heads $(4.69 \pm 0.06)$. This population represented $17.5 \%$ of the total sperm from ejaculates. Sub-population 2 (SP2) contained the highest values for head area and perimeter, with values of $35.77 \pm 1.24$, and $24.48 \pm 0.44$, respectively. About $42.5 \%$ of the spermatozoa from ejaculates were assigned to this sub-population. Sub-population 3 (SP3) included $20.0 \%$ of the sperm from all ejaculates, and was represented by shorter length $(8.49 \pm 0.22)$, with a smaller area $(34.16 \pm 1.07)$ and head perimeter $(23.72 \pm 0.51)$ values. This population had intermediate head shape values indicated by the ellipticity, elongation, and regularity values. Subpopulation 4 (SP4) contained $20.0 \%$ of the spermatozoa from the total ejaculate population, and these spermatozoa had the highest values for head length $(8.88 \pm 0.13)$, ellipticity $(2.03 \pm 0.02)$, and elongation $(0.34 \pm 0.01)$ (Table 4$)$.

\subsection{Predictive Capacity of Fertility}

The morphometric variables of the sperm with significant results in the ROC curve analysis are presented in Table 5. Sperm head length, ellipticity, elongation, and regularity showed significant, albeit limited, predictive capacity on the litter size variables (range: 0.56-0.60 AUC). Similarly, the sperm subpopulations showed limited predictive capacity on the litter size variables (data not shown). Cut-off points, with their sensitivities and specificities, are also presented in Table 5. Among the sperm shape variables, the best cut-off points to identify ejaculates with low fertility potential in relation to the number of mummies were $8.71 \mu \mathrm{m}$ for head length, 1.92 for ellipticity, and 0.31 for elongation. 
Table 4. Morphometry of sperm heads, head shape, and fertility variables (mean \pm s.d.) of the four ejaculate sub-populations (SPs) defined from boar semen samples.

\begin{tabular}{ccccc}
\hline Variable & $\mathbf{S P}_{\mathbf{1}}$ & $\mathbf{S P}_{\mathbf{2}}$ & $\mathbf{S P}_{\mathbf{3}}$ & $\mathbf{S P}_{\mathbf{4}}$ \\
\hline $\begin{array}{c}\text { Proportion of all } \\
\text { ejaculates (\%) }\end{array}$ & 17.50 & 42.50 & 20.00 & 20.00 \\
\hline Length & $8.57 \pm 0.13^{\mathrm{b}}$ & $8.81 \pm 0.18^{\mathrm{a}}$ & $8.49 \pm 0.22^{\mathrm{b}}$ & $8.88 \pm 0.13^{\mathrm{a}}$ \\
Width & $4.69 \pm 0.06^{\mathrm{a}}$ & $4.58 \pm 0.07^{\mathrm{b}}$ & $4.43 \pm 0.04^{\mathrm{c}}$ & $4.36^{\mathrm{a}} \pm 0.07^{\mathrm{d}}$ \\
Area & $35.63 \pm 0.69^{\mathrm{a}}$ & $35.77 \pm 1.24^{\mathrm{a}}$ & $34.16 \pm 1.07^{\mathrm{b}}$ & $34.65 \pm 0.92^{\mathrm{b}}$ \\
Perimeter & $24.04 \pm 0.27^{\mathrm{b}}$ & $24.48 \pm 0.44^{\mathrm{a}}$ & $23.72 \pm 0.51^{\mathrm{b}}$ & $24.20 \pm 0.32^{\mathrm{b}}$ \\
Ellipticity & $1.83 \pm 0.03^{\mathrm{c}}$ & $1.93 \pm 0.04^{\mathrm{b}}$ & $1.91^{\mathrm{a}} \pm 0.05^{\mathrm{b}}$ & $2.03 \pm 0.02^{\mathrm{a}}$ \\
Rugosity & $0.78 \pm 0.01^{\mathrm{a}}$ & $0.76 \pm 0.01^{\mathrm{b}}$ & $0.76 \pm 0.01^{\mathrm{b}}$ & $0.75 \pm 0.01^{\mathrm{c}}$ \\
Elongation & $0.29 \pm 0.01^{\mathrm{c}}$ & $0.32 \pm 0.01^{\mathrm{b}}$ & $0.31 \pm 0.01^{\mathrm{b}}$ & $0.34 \pm 0.01^{\mathrm{a}}$ \\
Regularity & $0.88 \pm 0.01^{\mathrm{a}}$ & $0.88 \pm 0.01^{\mathrm{a}}$ & $0.87^{\mathrm{b}} \pm 0.00^{\mathrm{b}}$ & $0.88 \pm 0.01^{\mathrm{a}}$ \\
\hline
\end{tabular}

s.d.: standard deviation. Number of ejaculates $=40$. Length $(\mathrm{L}, \mu \mathrm{m})$, width $(\mathrm{W}, \mu \mathrm{m})$, area $\left(\mathrm{A}, \mu \mathrm{m}^{2}\right)$, perimeter $(\mathrm{P}, \mu \mathrm{m})$, ellipticity $(\mathrm{L} / \mathrm{W})$, rugosity $\left(4 \pi \mathrm{A} / \mathrm{P}^{2}\right)$, elongation $((\mathrm{L}-\mathrm{W}) /(\mathrm{L}+\mathrm{W}))$, regularity $(\pi \mathrm{LW} / 4 \mathrm{~A}) .{ }^{\mathrm{a}-\mathrm{d}}$ Different letters indicate differences between ejaculate sub-populations for morphometric variables. $p<0.05$.

Table 5. Cut-off values of morphometric sperm variables significantly related to litter size variables calculated from receiver operating characteristic (ROC) curves.

\begin{tabular}{|c|c|c|c|c|c|}
\hline Variable & Cut-Off Value & Sensitivity (\%) & Specificity (\%) & Area ROC & $p$-Value \\
\hline \multicolumn{6}{|c|}{ Total born per litter } \\
\hline Area & 35.18 & 67.19 & 27.08 & 0.54 & 0.11 \\
\hline Perimeter & 24.26 & 68.66 & 28.26 & 0.55 & 0.10 \\
\hline \multicolumn{6}{|c|}{ Piglets born alive } \\
\hline Area & 35.18 & 67.19 & 27.08 & 0.53 & 0.17 \\
\hline Perimeter & 24.26 & 68.66 & 28.26 & 0.54 & 0.13 \\
\hline Ellipticity & 1.94 & 67.55 & 26.45 & 0.54 & 0.13 \\
\hline \multicolumn{6}{|c|}{ Piglets born dead } \\
\hline Regularity & 0.88 & 73.02 & 32.19 & 0.56 & 0.04 \\
\hline \multicolumn{6}{|c|}{ Number of mummies } \\
\hline Length & 8.71 & 71.74 & 31.34 & 0.59 & 0.02 \\
\hline Ellipticity & 1.92 & 73.08 & 33.62 & 0.59 & 0.02 \\
\hline Elongation & 0.31 & 73.08 & 33.62 & 0.60 & 0.02 \\
\hline
\end{tabular}

Length $(L, \mu \mathrm{m})$, width $(\mathrm{W}, \mu \mathrm{m})$, area $\left(\mathrm{A}, \mu \mathrm{m}^{2}\right)$, perimeter $(\mathrm{P}, \mu \mathrm{m})$, ellipticity $(\mathrm{L} / \mathrm{W})$, rugosity $\left(4 \pi \mathrm{A} / \mathrm{P}^{2}\right)$, elongation $((\mathrm{L}-\mathrm{W}) /(\mathrm{L}+\mathrm{W}))$, regularity $(\pi \mathrm{LW} / 4 \mathrm{~A})$.

\section{Discussion}

Fertility is a complex trait in which a wide range of sperm characteristics may be involved [40]. These fertility parameters can be expressed by several variables with distributions that can be continuous-where any value in the range of the distribution is possible (farrowing rate), or discrete-where only specific values can be returned (piglets born alive). The results of the present study indicate that the Pietrain $x$ Duroc crossbreed had larger sperm heads than the Pietrain boars. Similar results have been described in the larger spermatozoa head length, area, and perimeter of crossbred boars, as compared with purebred boars [41]. The morphometric variables related to the head size of the sperm were also significantly different among the individual Duroc $\times$ Pietrain or Pietrain boars, and between the Duroc $\times$ Pietrain and Pietrain boars. In stallions, differences in sperm head size within breeds [42,43] and between stallions [44] have been reported. Moreover, our results also showed that the sperm head size increased as the sperm concentration of the ejaculate increased, in agreement with previous studies in pigs [45]. In other species, such as dogs, it has been found that sperm concentration can influence the head size dimensions [46]. The head size and shape of the sperm may affect their motility [47] and 
fertilization capacity [45]. Overall, the percentage of motile sperm presented by the Pietrain males was lower than that of the Duroc $\times$ Pietrain boars.

Sperm length has been positively correlated with motility [48], and an inverse relationship has been described between sperm length and the effective time of maintenance of sperm cell motility, and thus its capacity for oocyte fertilization [49]. In pigs, lowerfertility boars also showed more elongated sperm heads [22]. Our study reports that boars with a larger litter size had significantly less elongated spermatozoa. Nevertheless, the mortality of piglets was greater in these males. This observation is in agreement with a previous study of Pietrain boars, in which the sperm heads of high-fertility boars were less elongated and smaller than those of lower fertility boars [22]. Although the sperm head morphometric parameters explained a variation in the litter size of $7.7 \%$, these results are partially explained by factors affecting the female [50]. The head shape also can affect the hydrodynamics of the spermatozoa, as sperm with elongated heads can move faster than those with more elliptical heads [51], and elongated heads have a relationship with male fertility rates [52]. Some authors have suggested that sperm with higher ellipticity values (head length/width) presented a lower progressiveness [53]. Our results indicate that there was a greater progressiveness in the Duroc $\times$ Pietrain boars than in the Pietrain boars, but no differences were found between the ellipticity of these two male lines. In humans, it has been observed that morphologically normal spermatozoa showed a faster acrosome reaction than the tapered, large, and small-headed types of spermatozoa [54,55]. Thus, morphological structure and functionality have a close relationship [12,55].

The outcome of this work indicated that crossbreeding influenced the head size and shape of boar sperm cells. The sperm from the Pietrain-line ejaculates had shorter and narrower heads, with a smaller head area and perimeter than sperm from the Duroc $\times$ Pietrain line. There are genetic factors to modeling shape and sperm head size $[6,7,41]$. The present study shows differences between the genetic lines of males for sperm head size. In rams, the distribution of sperm sub-populations had been associated with intra- and intermale differences [56]. While determining that morphometric differences occur between two male lines is biologically notable, it can be difficult to clearly connect these morphometric measurements to the boar semen used in assessments of sow fertility when artificially inseminated. In our study, this was most evident when the head shape morphometry was reviewed. Studies in humans demonstrated that the size and normal shape of sperm heads affect functions, such as the acrosome reaction [57] and the binding zone to the zona pellucida of the oocyte [58], which could affect the potential fertility of the male [59].

Sperm head size has also been related to fertility. Accordingly, variability in sperm head size has been correlated with variation in the chromatin structure of the cell nucleus [23]. Other authors have suggested that minor variations in the shape of sperm heads can be associated with changes in the chromatin structure in the spermatozoa nucleus, which can result in reduced fertility [60]. When the multivariate analysis was applied to the ejaculates analyzed for fertility variables and the spermatozoa size and head shape, discrete sub-populations (cluster centers) were generated based on the set number of two standardized principal components. In the analysis of sub-populations of sperm head dimensions, significant differences in the values for length, width, area, and perimeter were found between the sub-populations of Duroc $\times$ Pietrain and Pietrain boar sperm heads. The differences in the cluster populations were analyzed across all boar semen morphometric variables for size, head shape, and semen doses used in AI. Several studies have described the presence of different sub-populations within an ejaculate $[11,19,61-67]$. These sub-populations may be affected by external factors associated with semen, such as extender type or species $[68,69]$. Even the sperm sub-population distribution can vary depending on the statistical multivariate procedure used [70]. In boars, different morphometric sperm sub-populations were found and were categorized according to head size as large, small elongated, and small round, and these variables could have a functional involvement [31]. Past studies have associated sperm head morphometry and fertility variables in boars [22], male goats [26,71], stallions [27], rams [52], and rabbits [72], in which 
subsequent fertility was reduced with the lowest head size variables. When comparing male lines, we found that that boars with lower sperm head sizes generally had higher litter sizes. These findings were verified when we analyzed the sperm sub-populations in their ejaculate. The sperm sub-populations SP2 and SP3 presented more minor variations amongst each other than the sub-populations SP1 and SP4 did. Thus, there was less uniformity regarding the sperm head size variables between SP1-SP4, which suggests the idea that possibly the sperm competition between these sub-populations supports low levels of sperm competition, which could result in poor semen quality, as has been described in several studies on rodents $[73,74]$.

\section{Conclusions}

We have shown that morphometric analysis of boar ejaculates reveals morphometrically separate populations. Differences between sub-population sperm head sizes were displayed. Sperm morphometric variables may have a predictive capacity on the litter size variables. Clustering the sperm into sub-populations did not have a predictive capacity on the litter size variables.

Supplementary Materials: The following are available online at https://www.mdpi.com/2076-261 5/11/4/920/s1, Table S1: morphometric variables (mean \pm SEM) of the sperm size and sperm head shape of individual boars. Table S2: fertility variables (mean \pm SEM) of litter size and mortality of piglets born after artificial insemination with the semen of different boars.

Author Contributions: Conceptualization, A.V., E.R.S.R., J.L.Y. and C.S.; methodology, V.B., A.V.; software, V.B.; validation, V.B.; formal analysis, A.V., M.C.; investigation, V.B., A.V.; resources, A.V.; data curation, A.V., M.C.; writing—original draft preparation, A.V., V.B.; writing—review and editing, V.B., E.R.S.R., J.L.Y., A.V.; visualization, E.R.S.R., C.S., J.L.Y., A.V.; supervision, A.V.; project administration, A.V.; funding acquisition, A.V. All authors have read and agreed to the published version of the manuscript.

Funding: This research was funded by the Fundación para el Fomento y Promoción de la Investigación y Transferencia de Tecnología Agropecuaria de Costa Rica (FITTACORI) and the Costa Rica Institute of Technology (Vice-Chancellor's office of Research and Extension; VIE (Vicerrectoría de investigación y Extensión); Project 5402-2151-1015). The funders had no role in study design, data collection, analysis, decision to publish, or preparation of the manuscript.

Institutional Review Board Statement: The study was conducted according to the approval of the ethical principles of the Committee of Centro de Investigación y Desarrollo de la Agricultura Sostenible para el Trópico Húmedo at the Costa Rica Institute of Technology (CIDASTH-ITCR) according to Section 08/2020, article 1.0, DAGSC-100-2020.

Data Availability Statement: The data presented in this study are available within the article and/or its Supplementary Materials.

Acknowledgments: The authors thank the Costa Rica Institute of Technology (ITCR) and the Fundación para el Fomento y Promoción de la Investigación y Transferencia de Tecnología Agropecuaria de Costa Rica (FITTACORI) for financing this study. The authors are grateful to the staff of the Agropecuaria Los Sagitarios S.A. farm for supplying the boar ejaculates.

Conflicts of Interest: The authors declare no conflict of interest.

\section{References}

1. Gadea, J. Sperm factors related to in vitro and in vivo porcine fertility. Theriogenology 2005, 63, 431-444. [CrossRef] [PubMed]

2. Tsakmakidis, I.A.; Lymberopoulos, A.G.; Khalifa, T.A.A. Relationship between sperm quality traits and field-fertility of porcine semen. J. Vet. Sci. 2010, 11, 151-154. [CrossRef] [PubMed]

3. Rodriguez, A.L.; van Soom, A.; Arsenakis, I.; Maes, D. Boar management and semen handling factors affect the quality of boar extended semen. Porc. Health Manag. 2017, 3, 1-12. [CrossRef]

4. Kondracki, S.; Iwanina, M.; Wysokińska, A.; Huszno, M. Comparative analysis of Duroc and Pietrain boar sperm morphology. Acta Vet. Brno 2012, 81, 195-199. [CrossRef]

5. Kondracki, S.; Banaszewska, D.; Wysokińska, A.; Iwanina, M. The Effect of Sperm Concentration in the Ejaculate on Morphological Traits of Bull Spermatozoa. Folia Biol. 2012, 60, 85-91. [CrossRef] 
6. Saravia, F.; Núñez-Martínez, I.; Morán, J.; Soler, C.; Muriel, A.; Rodríguez-Martínez, H.; Peña, F. Differences in boar sperm head shape and dimensions recorded by computer-assisted sperm morphometry are not related to chromatin integrity. Theriogenology 2007, 68, 196-203. [CrossRef]

7. Thurston, L.M.; Watson, P.F.; Mileham, A.J.; Holt, W.V. Morphologically distinct sperm subpopulations defined by Fourier shape descriptors in fresh ejaculates correlate with variation in boar semen quality following cryopreservation. J. Androl. 2001, 22, 382-394.

8. Górski, K.; Kondracki, S.; Strachocka, K.; Wysokińska, A. Association of Ejaculate Sperm Counts with their Morphological and Morphometric Characteristics in Hypor Boars. Ann. Anim. Sci. 2017, 17, 1043-1052. [CrossRef]

9. Górski, K.; Kondracki, S.; Wysokińska, A. Ejaculate traits and sperm morphology depending on ejaculate volume in Duroc boars. J. Vet. Res. 2017, 61, 121-125. [CrossRef]

10. Soler, C.; Alambiaga, A.; Martí, M.A.; García-Molina, A.; Valverde, A.; Contell, J.; Campos, M. Dog sperm head morphometry: Its diversity and evolution. Asian J. Androl. 2017, 19, 149-153. [CrossRef]

11. Valverde, A.; Arenán, H.; Sancho, M.; Contell, J.; Yániz, J.; Fernández, A.; Soler, C. Morphometry and subpopulation structure of Holstein bull spermatozoa: Variations in ejaculates and cryopreservation straws. Asian J. Androl. 2016, 18, 851-857. [CrossRef]

12. Maroto-Morales, A.; García-Álvarez, O.; Ramón, M.; Martínez-Pastor, F.; Fernández-Santos, M.R.; Soler, A.J.; Garde, J.J. Current status and potential of morphometric sperm analysis. Asian J. Androl. 2016, 18, 863-870. [CrossRef]

13. Soler, C.; Cooper, T.G.; Valverde, A.; Yániz, J.L. Afterword to Sperm morphometrics today and tomorrow special issue in Asian Journal of Andrology. Asian J. Androl. 2016, 18, 895-897. [CrossRef]

14. Gage, M.J.G. Mammalian sperm morphometry. Proc. R. Soc. B Biol. Sci. 1998, 265, 97-103. [CrossRef]

15. Meisner, A.D.; Klaus, A.V.; O'Leary, M.A. Sperm head morphology in 36 species of artiodactylans, perissodactylans, and cetaceans (Mammalia). J. Morphol. 2004, 263, 179-202. [CrossRef]

16. Peña, F.J.; Saravia, F.; García-Herreros, M.; Núñezmartínez, I.; Tapia, J.A.; Wallgren, M.; Rodriguez-Martinez, H.; Johannisson, A. Identification of Sperm Morphometric Subpopulations in Two Different Portions of the Boar Ejaculate and Its Relation to Postthaw Quality. J. Androl. 2005, 26, 716-723. [CrossRef]

17. Wysokińska, A.; Kondracki, S.; Banaszewska, D. Morphometrical characteristics of spermatozoa in Polish Landrace boars with regard to the number of spermatozoa in an ejaculate. Reprod. Biol. 2009, 9, 271-282. [CrossRef]

18. Górski, K.; Kondracki, S.; Wysokińska, A.; Nazaruk, A. The Importance of Ejaculate Volume for the Physical Parameters of Ejaculates and Sperm Morphology of Hypor Boars. Kafkas Univ. Vet. Fak. Derg. 2016, 22, 493-501.

19. Soler, C.; Contell, J.; Bori, L.; Sancho, M.; García-Molina, A.; Valverde, A.; Segarvall, J. Sperm kinematic, head morphometric and kinetic-morphometric subpopulations in the blue fox (Alopex lagopus). Asian J. Androl. 2017, 19, 154-159. [CrossRef]

20. Yániz, J.L.; Vicente-Fiel, S.; Soler, C.; Recreo, P.; Carretero, T.; Bono, A.; Berné, J.M.; Santolaria, P. Comparison of different statistical approaches to evaluate morphometric sperm subpopulations in man. Asian J. Androl. 2016, 18, 819-823. [CrossRef]

21. Martínez-Rodríguez, C.; Alvarez, M.; López-Urueña, E.; Gomes-Alves, S.; Anel-López, L.; Tizado, J.E.; Anel, L.; de Paz, P. Head morphology of ram spermatozoa is associated with their ability to migrate in vitro and correlates with fertility. Reprod. Fertil. Dev. 2016, 28, 1825-1837. [CrossRef]

22. Hirai, M.; Boersma, A.; Hoeflich, A.; Wolf, E.; Foll, J.; Aumüller, T.R.; Braun, J. Objectively measured sperm motility and sperm head morphometry in boars (Sus scrofa): Relation to fertility and seminal plasma growth factors. J. Androl. 2001, 22, 104-110.

23. Sailer, B.L.; Jost, L.K.; Evenson, D.P. Bull sperm head morphometry related to abnormal chromatin structure and fertility. Cytometry 1996, 24, 167-173. [CrossRef]

24. Aggarwal, R.; Ahlawat, S.; Kumar, Y.; Panwar, P.; Singh, K.; Bhargava, M. Biometry of frozen-thawed sperm from eight breeds of Indian buffaloes (Bubalus bubalis). Theriogenology 2007, 68, 682-686. [CrossRef]

25. De Paz, P.; Mata-Campuzano, M.; Tizado, E.J.; Alvarez, M.; Alvarez-Rodriguez, M.; Herráez, P.; Anel, L. The relationship between ram sperm head morphometry and fertility depends on the procedures of acquisition and analysis used. Theriogenology 2011, 76, 1313-1325. [CrossRef]

26. Hidalgo, M.; Rodríguez, I.; Dorado, J. The effect of cryopreservation on sperm head morphometry in Florida male goat related to sperm freezability. Anim. Reprod. Sci. 2007, 100, 61-72. [CrossRef]

27. Casey, P.; Gravance, C.; Davis, R.; Chabot, D.; Liu, I. Morphometric differences in sperm head dimensions of fertile and subfertile stallions. Theriogenology 1997, 47, 575-582. [CrossRef]

28. Núñez-Martínez, I.; Moran, J.M.; Peña, F.J. Sperm indexes obtained using computer-assisted morphometry provide a forecast of the freezability of canine sperm. Int. J. Androl. 2007, 30, 182-189. [CrossRef]

29. Kruger, T.F.; Dutoit, T.C.; Franken, D.R.; Acosta, A.A.; Oehninger, S.C.; Menkveld, R.; Lombard, C.J. A new computerized method of reading sperm morphology (strict criteria) is as efficient as technician reading. Fertil. Steril. 1993, 59, 202-209. [CrossRef]

30. Vicente-Fiel, S.; Palacín, I.; Santolaria, P.; Yániz, J. A comparative study of sperm morphometric subpopulations in cattle, goat, sheep and pigs using a computer-assisted fluorescence method (CASMA-F). Anim. Reprod. Sci. 2013, 139, 182-189. [CrossRef]

31. Vicente-Fiel, S.; Palacín, I.; Santolaria, P.; Hidalgo, C.; Silvestre, M.A.; Arrebola, F.A.; Yániz, J. A comparative study of the sperm nuclear morphometry in cattle, goat, sheep, and pigs using a new computer-assisted method (CASMA-F). Theriogenology 2013, 79, 436-442. [CrossRef]

32. National Research Council. Nutrient Requirements of Swine; National Academies Press: Washington, DC, USA, 2012.

33. Hancock, J.; Hovell, G. The collection of boar semen. Vet. Rec. 1959, 71, 664-665. 
34. World Health Organization. WHO Laboratory Manual for the Examination and Processing of Human Semen; World Health Organization: Geneva, Switzerland, 2010; ISBN 9789241547789.

35. Boersma, A.; Braun, J.; Stolla, R. Influence of Random Factors and Two Different Staining Procedures on Computer-assisted Sperm Head Morphometry in Bulls. Reprod. Domest. Anim. 1999, 34, 77-82. [CrossRef]

36. Spencer, N. Essentials of Multivariate Data Analysis; Chapman and Hall/CRC Press: New York, NY, USA, $2013 ;$ ISBN 9781466584785.

37. Kaiser, H.F. The varimax criterion for analytic rotation in factor analysis. Psychometrika 1958, 23, 187-200. [CrossRef]

38. Kaufman, L.; Rousseeuw, P. Finding Groups in Data: An Introduction to Cluster Analysis; Wiley: Hoboken, NJ, USA, 2005; ISBN 9780471735786 .

39. Murtagh, F.; Legendre, P. Ward's Hierarchical Agglomerative Clustering Method: Which Algorithms Implement Ward's Criterion? J. Classif. 2014, 31, 274-295. [CrossRef]

40. Kölle, S.; Reese, S.; Kummer, W. New aspects of gamete transport, fertilization, and embryonic development in the oviduct gained by means of live cell imaging. Theriogenology 2010, 73, 786-795. [CrossRef]

41. Wysokińska, A.; Kondracki, S. Heterosis for morphometric characteristics of sperm cells from Duroc x Pietrain crossbred boars Anim. Reprod. Sci. 2019, 211, 106217. [CrossRef]

42. Ball, B.; Mohammed, H. Morphometry of stallion spermatozoa by computer-assisted image analysis. Theriogenology 1995, 44, 367-377. [CrossRef]

43. Phetudomsinsuk, K.; Sirinarumitr, K.; Laikul, A.; Pinyopummin, A. Morphology and head morphometric characters of sperm in Thai native crossbred stallions. Acta Vet. Scand. 2008, 50, 41. [CrossRef]

44. Hidalgo, M.; Rodríguez, I.; Dorado, J.; Soler, C. Morphometric classification of Spanish thoroughbred stallion sperm heads. Anim. Reprod. Sci. 2008, 103, 374-378. [CrossRef]

45. Górski, K.; Kondracki, S.; Wysokińska, A.; Iwanina, M. Dependence of sperm morphology and ejaculate characteristics on sperm concentration in the ejaculates of Hypor boars. J. Vet. Res. 2018, 62, 353-357. [CrossRef]

46. Rijsselaere, T.; Soom, A.; Hoflack, G.; Meas, D.; Kruif, A. Automated sperm morphometry and morphology analysis of canine semen by the Hamilton-Thorne analyser. Theriogenology 2004, 62, 1292-1306. [CrossRef] [PubMed]

47. Gillies, E.A.; Cannon, R.M.; Green, R.B.; Pacey, A.A. Hydrodynamic propulsion of human sperm. J. Fluid Mech. 2009, 625, 445. [CrossRef]

48. Mossman, J.; Slate, J.; Humphries, S.; Birkhead, T. Sperm morphology and velocity are genetically codetermined in the Zebra finch. Evolution 2009, 63, 2730-2737. [CrossRef]

49. Gomendio, M.; Roldan, E.R.S. Coevolution between male ejaculates and female reproductive biology in eutherian mammals. Proc. R. Soc. B Biol. Sci. 1993, 252, 7-12. [CrossRef]

50. Quintero-Moreno, A.; Rigau, T.; Rodríguez-Gil, J. Multivariate Cluster Analysis Regression Procedures as Tools to Identify Motile Sperm Subpopulations in Rabbit Semen and to Predict Semen Fertility and Litter Size. Reprod. Domest. Anim. 2007, 42, 312-319. [CrossRef] [PubMed]

51. Malo, A.F.; Gomendio, M.; Garde, J.J.; Lang-Lenton, B.; Soler, A.J.; Roldán, E.R.S. Sperm design and sperm function. Biol. Lett. 2006, 2, 246-249. [CrossRef]

52. Maroto-Morales, A.; Ramon, M.; García-Álvarez, O.; Montoro, V.; Soler, A.J.; Fernández-Santos, M.; Roldan, E.; Pérez-Guzmán, M.; Garde, J. Sperm head phenotype and male fertility in ram semen. Theriogenology 2015, 84, 1536-1541. [CrossRef]

53. Gil, M.; García-Herreros, M.; Barón, F.; Aparicio, I.; Santos, A.; García-Marín, L. Morphometry of porcine spermatozoa and its functional significance in relation with the motility parameters in fresh semen. Theriogenology 2009, 71, 254-263. [CrossRef]

54. Gatimel, N.; Moreau, J.; Parinaud, J.; Léandri, R.D. Sperm morphology: Assessment, pathophysiology, clinical relevance, and state of the art in 2017. Andrology 2017, 5, 845-862. [CrossRef]

55. Franken, D.R.; Bastiaan, H.S.; Kidson, A.; Wranz, P.; Habenicht, U.-F. Zona pellucida mediated acrosome reaction and sperm morphology. Andrology 2009, 29, 311-317. [CrossRef]

56. Maroto-Morales, A.; Ramon, M.; García-Alvarez, O.; Soler, A.J.; Fernández-Santos, M.; Roldan, E.; Gomendio, M.; Pérez-Guzmán, M.; Garde, J. Morphometrically-distinct sperm subpopulations defined by a multistep statistical procedure in Ram ejaculates: Intra- and interindividual variation. Theriogenology 2012, 77, 1529-1539. [CrossRef]

57. Menkveld, R.; El-Garem, Y.; Schill, W.-B.; Henkel, R. Relationship Between Human Sperm Morphology and Acrosomal Function. J. Assist. Reprod. Genet. 2003, 20, 432-438. [CrossRef]

58. García-Vázquez, F.A.; Gadea, J.; Matás, C.; Holt, W.V. Importance of sperm morphology during their transport and fertilization in mammals. Asian J. Androl. 2016, 18, 844-850. [CrossRef]

59. Menkveld, R. Clinical significance of the low normal sperm morphology value as proposed in the fifth edition of the WHO Laboratory Manual for the Examination and Processing of Human Semen. Asian J. Androl. 2010, 12, 47-58. [CrossRef]

60. Evenson, D.P.; Wixon, R. Clinical aspects of sperm DNA fragmentation detection and male infertility. Theriogenology 2006, 65, 979-991. [CrossRef]

61. Holt, W.V.; van Look, K.J.W. Concepts in sperm heterogeneity, sperm selection and sperm competition as biological foundations for laboratory tests of semen quality. Reproduction 2004, 127, 527-535. [CrossRef]

62. Valverde, A.; Madrigal, M.; Caldeira, C.; Bompart, D.; de Murga, J.N.; Arnau, S.; Soler, C. Effect of frame rate capture frequency on sperm kinematic parameters and subpopulation structure definition in boars, analysed with a CASA-Mot system. Reprod. Domest. Anim. 2019, 54, 167-175. [CrossRef] 
63. García-Molina, A.; Valverde, A.; Bompart, D.; Caldeira, C.; Vendrell, A.; Soler, C. Updating semen analysis: A subpopulation approach. Asian J. Androl. 2020, 22, 118-119. [CrossRef]

64. Caldeira, C.; García-Molina, A.; Valverde, A.; Bompart, D.; Hassane, M.; Martin, P.; Soler, C. Comparison of sperm motility subpopulation structure among wild anadromous and farmed male Atlantic salmon (Salmo salar) parr using a CASA system. Reprod. Fertil. Dev. 2018, 30, 897-906. [CrossRef]

65. Abarca, A.V.; Castro-Morales, O.; Mdrigal-Valverde, M. Sperm kinematics and morphometric subpopulations analysis with CASA systems: A review. Rev. Biol. Trop. 2019, 67, 1473-1487. [CrossRef]

66. Valverde, A.; Madrigal-Valverde, M.; Castro-Morales, O.; Gadea-Rivas, A.; Johnston, S.; Soler, C. Kinematic and head morphometric characterisation of spermatozoa from the Brown Caiman (Caiman crocodilus fuscus). Anim. Reprod. Sci. 2019, 207, 9-20. [CrossRef]

67. Sadeghi, S.; García-Molina, A.; Celma, F.; Valverde, A.; Fereidounfar, S.; Soler, C. Morphometric comparison by the ISAS ${ }^{\circledR}$ CASADNA system of two techniques for the evaluation of DNA fragmentation in human spermatozoa. Asian J. Androl. 2016, 18, 835-839. [CrossRef]

68. Víquez, L.; Barquero, V.; Soler, C.; Roldan, E.R.; Valverde, A. Kinematic Sub-Populations in Bull Spermatozoa: A Comparison of Classical and Bayesian Approaches. Biology 2020, 9, 138. [CrossRef]

69. Valverde, A.; Castro-Morales, O.; Madrigal-Valverde, M.; Camacho, M.; Barquero, V.; Soler, C.; Roldan, E.R.S. Sperm kinematic subpopulations of the American crocodile (Crocodylus acutus). PLoS ONE 2021, 16, e0248270. [CrossRef]

70. Ibanescu, I.; Siuda, M.; Bollwein, H. Motile sperm subpopulations in bull semen using different clustering approachesAssociations with flow cytometric sperm characteristics and fertility. Anim. Reprod. Sci. 2020, 215, 106329. [CrossRef]

71. Marco-Jiménez, F.; Viudes-De-Castro, M.; Balasch, S.; Mocé, E.; Silvestre, M.A.; Gómez, E.; Vicente, J. Morphometric changes in goat sperm heads induced by cryopreservation. Cryobiology 2006, 52, 295-304. [CrossRef]

72. Marco-Jiménez, F.; Balasch, S.; Vicente, J.S.; Lavara, R.; Viudes-De-Castro, M.P.; Mocé, E. Detection of sub-fertile rabbits by means of sperm head morphometric analysis. Impreso 2005, 80 .

73. Varea-Sánchez, M.; Montoto, L.G.; Tourmente, M.; Roldan, E.R.S. Postcopulatory Sexual Selection Results in Spermatozoa with More Uniform Head and Flagellum Sizes in Rodents. PLoS ONE 2014, 9, e108148. [CrossRef]

74. Thitipramote, N.; Suwanjarat, J.; Leigh, C.; Breed, W.G. Variation in sperm morphology of a murine rodent from South-East Asia: The Greater Bandicoot Rat, Bandicota indica. Acta Zool. 2010, 92, 201-205. [CrossRef] 